\title{
A MODEL FOR RECONCILING ISLAMIC TEACHINGS WITH THE INTELLECTUAL AND SCIENTIFIC ACHIEVEMENTS OF MODERNITY
}

\author{
Javad Fakhkhar Toosi *
}

\begin{abstract}
The current article seeks to present a model that reconciles Islamic teachings with the intellectual and scientific achievements of modernity. It attempts to develop a model that systematises the discourse on Islam and modernity while preserving its Islamic identity using qualitative methods. Thus, this article introduces a model called 'moderate Islamic modernism'. This model does not acknowledge the achievements of modernity in their entirety, but only those intellectual and scientific achievements that are free from certain bias elements. This article will first distinguish between the proposed moderate model and that of 'extreme Islamic modernism'. Secondly, this article compares the model with 'Islamic traditionalism'. In brief, the proposed moderate model advocates the reconciliation of Islamic teachings with the intellectual and scientific achievements of modernity, as well as reforming the traditional method. The article concludes that the 'moderate Islamic modernism' approach to modernity and its rational elements not only provides a theoretical solution but is also compatible with genuine Islamic teachings. It is hoped that the two methods proposed by the model, particularly its method for differentiating elements within modernity, and its new approach on Islamic studies, will benefit future research on the subject matter.
\end{abstract}

Keywords: Rationality; Modernism; Logic; Islamic tradionalism, Modernity.

\section{Introduction}

Modernity refers to the era that began with the Renaissance and continued with the Enlightenment. ${ }^{1}$ The end of modernity, on the other hand, is often marked by the end of the twentieth century and the arrival of postmodernism. ${ }^{2}$ While there were many intellectual movements during this period, ${ }^{3}$ these movements have various common indicators that make them distinctly modern. A complete and comprehensive definition of modernity requires careful consideration of all 
dimensions that distinguish modern times from other periods. This article will not focus on discussing the definition of modernity. Rather, it will focus on modernity as an era that started after the Middle Ages. From this period, science and rationalism began to form the basis of philosophy, sociology, economics, and policy. ${ }^{4}$ Human achievements in this era were not limited to philosophy and ontology, but included the political, social, economic, educational, ethical and other fields of life. ${ }^{5}$ This study will mostly refer to 'modernity' in relation to the achievements of humankind from the period of the 'Enlightenment' and the 'Industrial Revolution' onwards. This study will also adopt Irving Sandler's concept of 'avant-garde' as the central definition of modernity: "modernism can also be viewed broadly as unbounded, multiple, inclusive of every tendency that seems at all 'progressive,' that is, different from what has been." 6

Modernity continues to pose a great challenge to many Muslim scholars regarding its compatibility with Islamic teachings. ${ }^{7}$ One of the most critical issues is to explain how Islam approaches the question of modernity and its elements. Two main approaches can be identified in the context of this encounter: First, the approach of Muslim traditionalists who advocate a return to established Islamic teachings. This return is equivalent to the negation of modernity and its elements and achievements. ${ }^{8}$ There are also extremist tendencies within the traditionalists that seek to restore the glory of early Islamic civilisation by suggesting that the only solution to modern problems is to simulate the society at the time of the Prophet, despite current contextual differences. ${ }^{9}$ The second approach is by the Muslim modernists. Although Muslim modernists may adopt different intellectual streams, they generally share a standard view on the need to adapt Islamic teachings to modernity and its elements..$^{10}$ The advent of this approach can be attributed to Jamal al-Din Asad Abadi. ${ }^{11}$ It has continued to be adopted through to the present, especially by the 'New Mu'tazilah'. ${ }^{12}$

Regarding the study of Islam and modernity, many scholars have a positive attitude toward modernity, but most of them resort to describing the two extremes, rather than discussing the necessity of a positive approach to modernity or developing a moderate model. For example, Mohammed Bamyeh focused on describing and explaining modern Islam, ${ }^{13}$ while Mustapha Kamal Pasha addresses the matter by questioning "the hegemonic view pervasive in both secular and post-secular theorising of the fiction of immutability of faith in the ICZs. ${ }^{14}$ Dietrich Jung also adopted a binary approach to the matter. ${ }^{15}$ The fundamental difference between the current article and the aforementioned works is that this article seeks to present a model for an Islamic approach to modernity. Describing the stat us quo or explaining the challenges of reconciling the traditional approach with the requirements of modernity is not the subject of our discussion. Also, we do not discuss the effects of modernity on Muslim 
countries as this has been done by Amina Jamal ${ }^{16}$ and Marc-Antoine and his colleagues. ${ }^{17}$ It is worth noting that some of these researchers, in addition to having a positive approach towards modernity, rely heavily on external studies. Their studies do not refer to evidence from within the Islamic sources but consider modern approaches as inevitable. Among those that have adopted such an approach are Eickelman, ${ }^{18}$ Bassam Tibi, ${ }^{19}$ Abdolkarim Soroush, ${ }^{20}$ and Mohammad Mojtahed Shabestari. ${ }^{21}$

Other researches have chosen a negative approach to modernity, or have focused their studies on such an approach, such as Khosropanah Abdolhossein ${ }^{22}$ or Seyyed Vali Reza Nasr. ${ }^{23}$ This article adopts a different path by attempting to present a positive approach to modernity that remains rooted in traditional Islamic studies.

The present article is divided into two parts. In the first section, we discuss the achievements of modernity, while the second part introduces a model for adapting Islamic teachings to the achievements of modernity. Within that context, the current study aims to identify the nature of modern phenomena. ${ }^{24}$ First, the article will explain how to harmonise Islamic teachings with the intellectual and scientific achievements of modernity. Second, the model will distinguish between what constitutes Islamic and Western achievements.

The present study is also a type of theoretical study that utilises rational and syllogistic reasoning methods. ${ }^{25}$ These methods will be utilised in reconciling Islamic teachings with the intellectual and scientific achievements of modernity.

Finally, we should note that the article examines the existing capacities of Islam and its compatibility with modernity. In other words, it is an internal study (as opposed to external study) that examines propositions and statements utilising on relevant insider sources. ${ }^{26}$

\section{The Achievements of Modernity from an Islamic Perspective}

In Islam, not all the achievements of modernity should be acknowledged. Many of them are based on Western lifestyle and culture. Only those that are based on scientific findings and the achievements of the human intellect will be considered. In regard to what is considered compatible between Islam and the achievements of modernity, the model refers to this category.

\section{The Intellectual and Scientific Achievements of Modernity}

First and foremost, there is a need to specify the achievements of modernity. The proposed model defines the achievements of modernity and its elements 
as the wisdom and scientific breakthroughs achieved after the Enlightenment and that are accepted by the majority of humankind, throughout the world. Modern civilisation is based on these achievements, which include rationality, freedom, democracy, equality, justice, autonomy, individualism, nationalism, development, universalism, homogenisation, mechanisation, secularisation, and so on. While the advent of postmodernism has brought many criticisms of modernism, many of the values of the modern era and its norms remain the pillars of modern human civilisation and are accepted by most human societies. Many international conventions, international laws, and modern theories continue to be based on such values, norms and foundations.

The achievements of modernity can be categorised into two. The first category comprises achievements based on definite scientific ideas or universal human rationality. The second category constitutes achievements that are based on Western lifestyles, education, environmental influences, human inclinations and so on. It is important to distinguish between these two categories. Mistaking rationality or reason with base inclinations or desire has been a disaster in today's societies, especially in Western countries. In many cases, what is perceived and considered as reason and rationality is in fact instinctive desire and worldly inclination. Therefore, separating the two from each other is a fundamental concern. In the next section, the article will elaborate on how to make this distinction.

\section{Recognition of the Intellectual and Scientific Achievements of Modernity}

A question emerges as to the criteria for deciding when to prioritise rationality over scripture in case of contradiction? In response to this question, this article adopts the following indicators: whenever a position is universally accepted by the wise of the world, and the acceptance of the position is not affected by a dependence on a particular religion, country, nation, culture, race, and so on, then the statement is rational. Otherwise, the position cannot be considered rational. For example, the impermissibility of oppression is a universal position accepted by all, regardless of religion, culture, country, nation and race. It is, therefore, a rational position. On the other hand, homosexual marriage (which is legal in some Western countries) does not fulfil that requirement. Since such an issue is heavily influenced by culture, religion, and the interest of a minority group, such a position cannot be considered rational. In theory, this is a clear and precise indicator, but is there a way in which we can determine which positions are accepted by the wise and the learned (regardless of their particular affinities) or decide which positions are the result of unacceptable biases? 
Muslim scholars in the field of logic divide logical statements (al-qadaya) into different types. They believe that some statements are rational and based on reason, while others are not. On this basis, whenever a person doubts a statement, he can evaluate it based on a set of logical rules. This article considers statements that are accepted by the wise and the learned of the world to have reached the level of certainty (al-yaqiniyyat), defined as a one hundred per cent certainty in which there is no doubt. ${ }^{27}$ Statements that have reached this level of certainty may include: (1) Primary statements (al-awwaliyyat), which are statements that the mind believes without any reason beyond themselves; (2) Observable statements (al-mushahidat), ${ }^{28}$ (3) Proven statements (al-mujarrabat), or statements that are proven by repeated experience, ${ }^{29}$ (4) Successive statements (al-mutawatirat), as statements that are conveyed by innumerable people, which lends credence to the reliability and accuracy of those statement; ${ }^{30}$ (5) Surmised statements (al-hadsiyyat), or statements that have no apparent evidence but are supported by a strong intuition which eliminates any doubt; and (6) Statements that originate from the innate nature of humanity (al-fitriyyat). ${ }^{31}$

In addition to al-yaqiniyyat statements, there are three other categories of statements that are rationally accepted. The first type is generally accepted statements (al-mashhurat), referring to matters that have become general knowledge among the people and are widely accepted. ${ }^{32}$ It should be noted, however, that not all al-mashhurat statements are accepted by the wise. Some al-mashhurat statements are self-evident, like primary statements (alawwaliyyat) and innate statements (al-fitriyyat), which have been mentioned as examples of al-yaqiniyyat. The second type is al-ta'dibat al-salahiyyah, which means accepted statement or principle based on a universal benefit (for instance, the virtue of justice). The third type is al-musallamat, or statements that are generally accepted based on science and which are often rooted in common sense. ${ }^{33}$

In brief, rational or intellectual statements that have a high level of certainty can be categorised into four types: al-yaqiniyyat, al-mashhurat, al-ta'dibat alsalahiyyah, and al-musallamat. Among the achievements of modernity, many can be categorised under these four types.

Despite certain statements having a high level of certainty, it is possible they did not reach that level before the age of modernity. For instance, primary statements (al-awwaliyyat) may have not seemed reasonable in the pre-modern era due to different perceptions and availability of evidence. The same principle applies to observable statements (al-mushahidat), proven statements (almujarrabat), and successive statements (al-mutawatirat) due to the continuous development and acquisition of knowledge. Therefore, it is possible for a statement belonging to these four categories to achieve certainty only after 
the age of modernity and not in pre-modern times. For this reason, the model proposed by this article will only take into account human achievements after the era of modernity before assigning them into the four categories of statements.

\section{A Model to Study Islamic Teachings Regarding the Achievements of Modernity}

Islamic traditionalism insists on moulding the Islamic community based on the Prophetic model, as well as purifying Islam of the heresies that were subsequently introduced into the religion, either in the form of new interpretations or innovation. ${ }^{34}$ In contrast, the primary goal of Islamic modernism revolves around the need to adapt elements and achievements of modernity to Islamic teachings. ${ }^{35}$ However, we cannot ignore the fact that Islamic modernism includes different directions. Historically, Islamic modernism can be classified into several categories. ${ }^{36}$ Within the current context, what matters is a classification based on orientations. In this regard, I divide Islamic modernism into extreme modernism and moderate modernism.

The moderate Islamic modernism model is based on two elements: 1) Defining a border with extreme Islamic modernism, and 2) Differentiating the model from Muslim traditionalism. These two elements will be the subject of the following discussion.

\section{Defining a Border with Extreme Islamic Modernism}

There are two factors that may transform moderate modernism into extreme modernism: scope and method.

1. Scope: For extreme Islamic modernism, the elements and achievements of modernity take a central position, ${ }^{37}$ regardless of whether those elements are definitive scientific achievements, a result of common reason, or a product of the lifestyle of the twenty-first century. Extreme Islamic modernism insists on forcing Islamic teachings to conform to modernity in its entirety. Such an approach can be attributed to Mohammed Arkun (1928-2010), Mohammed 'Abid al-Jabri (1936-2010), Amin al-Khuli (1895-1966), Ibrahim Fawzi, as well as Mohammad Mojtahed Shabestari (b.1936) and Abdolkarim Soroush (b.1945). In contrast, moderate modernists do not acknowledge the achievements of modernity in their entirety. By dividing the elements of modernity into two groups (as previously mentioned), ${ }^{38}$ Islamic interpretation only needs to maintain consistency with the first group: modern achievements that are based on definitive scientific findings or common human reason. 
2. Method: Extreme Islamic modernism relies entirely on Western scientific methods. ${ }^{39}$ As a result, extremist Islamic modernists do not recognise the traditional method of inference that has been accepted by Muslim scholars in the past. They only accept modern methods for their research, such as structuralism, hermeneutics, genealogy, and semiotics. Extreme Islamic modernists do not simply employ these methods as complementary to the traditional method, but completely replace the traditional method with them..$^{40}$ This is the methodological difference between moderate Islamic modernism and extreme Islamic modernism.

Moderate Islamic modernism provides a consistent interpretation of Islamic teachings by adhering to the traditional methods already adopted by Muslim scholars. This approach is governed by two tenets: first, belief in the capacity of Islamic resources to provide interpretations consistent with modernity and solutions to new issues, and, second, belief in the capacity of the traditional method to extract new and modern statements. This article will address the necessity of using this method in another section. In this section, the proposed model of moderate Islamic modernism will be elaborated.

Moderate Islamic modernism emphasises the holiness of the Qur'an and sunnah; in cases of any apparent contradictions between these sources and modern findings, specific steps will be taken, including the study of the chain of narrators. If the chain of narrators is proven sound and authentic, such statements will be interpreted and not abandoned. Among the modern methods, only hermeneutics is accepted by moderate Islamic modernism, but will only be deployed within the shell of the traditional approach, not along with it.

To sum up, the moderate Islamic modernism model necessitates the following:

1. Having sufficient knowledge in relevant Islamic sciences: strong familiarity with the traditions of the Prophet and his Companions; and competency in the established methods and rules of usul al-fiqh. Equally important are hadith-related disciplines, such as isnad al-riwayat, 'ilm al-rijal and ilm al-hadith. The rules for understanding the texts of narratives are also integral to the traditional method. In order to be able to observe these rules, it is necessary to learn Arabic grammar (al-sarf wa al-nahw); eloquence and rhetoric ('ulum al-balaghah); and Arabic linguistics. ${ }^{41}$

2. The practice of ijtihad: Ijtihad is a set of exploratory activities for extracting religious rulings, carried out by a competent Muslim scholar. ${ }^{42}$ The moderate Islamic modernism model refrains from blind imitation, but at the same time respects the legacy of past scholarship. It tries its 
best to interpret and justify the words of the past in a manner that is consistent with modern perceptions.

3. Internality of studies: The traditional method is intra-religious, ${ }^{43}$ that is, the researcher does not view Islamic resources as an outsider, but rather from the inside, therefore relying on methodological tools defined by the Islamic sciences. In this way, moderate Islamic modernism can be distinguished from extreme Islamic modernism, which prioritises methods and resources developed outside the religion. ${ }^{44}$

Finally, this article wishes to point out a significant difference between the 'traditional method of jurisprudence' (usul fiqh) and 'traditional jurisprudence' (fiqh). Traditional jurisprudence refers to existing jurisprudential positions which are, in many cases, incompatible with modernity and its elements. On the other hand, the traditional method refers to the methods and ratio-legal instruments utilised by Muslim scholars to derive religious positions or legislation.

The traditional method emphasises the importance of expertise and knowledge in the sciences relating to understanding the Qur' an and the Prophet's traditions. ${ }^{45}$ Since these texts are in Arabic, knowledge of 'ilm al-lughah, which encapsulates Arabic grammar rules, word science, and its art of eloquence and rhetoric, is integral. ${ }^{46}$ Such strict requirements should prevent mistakes in interpreting the Qur'an and sunnah. Aside from a basic grasp of Arabic linguistics, the science of interpretation (al-tafsir) and hadith ('ilm al-hadith) are also vital for understanding the Qur'an and sunnah. Additionally, it is necessary to study the chain of narrators of hadiths based on the discipline of 'ilm al-rijal. ${ }^{47}$ Knowledge of usul al-fiqh provides the necessary guidance on the many rules and principles for interpreting the text, such as analogy (al-qiyas), blocking the means (sadd aldhara' $i$ ') and binding utility (al-maslihah al-mulzimah) ${ }^{48}$

The traditional method, in addition to its complex epistemology, has three central criteria: expertise in sciences related to the primary sources of Qur'an and sunnah; expertise in secondary religious sources like ijma' and 'aql; and, finally, the discipline to observe the abovementioned rules.

Notwithstanding the established and well-developed nature of traditional methods, such are not without flaws or devoid of opportunity for improvement. I argue that all the critiques put forth by Muslim modernists against the traditional method primarily focus on the latter's shortcomings regarding answering modern questions. ${ }^{49}$ As a result, Muslim modernists often ignore the necessity of using the traditional method. ${ }^{50}$ Abandoning the traditional method, however, will render the approach to the texts inadequate and problematic. On the other hand, without correction and reform, the traditional method will continue to stumble when facing modern questions. 


\section{Differentiating from Islamic Traditionalism}

Just as the moderate Islamic modernism model has two fundamental differences in comparison with extreme Islamic modernism, it also has two significant differences with Islamic traditionalism: 1) Reconciling Islamic teachings with the intellectual and scientific achievements of modernity, and 2) The need to reform the traditional method.

Concerning the necessity of reconciling Islamic teachings with the intellectual and scientific achievements of modernity, the moderate model recommends a positive approach towards modernism, one that acknowledges those achievements of modernity that are based on definite scientific ideas or human reason. If there is a conflict between such statements and a religious proposition, the latter must be interpreted and justified in a way that is compatible with rationality, or it will have to be abandoned (especially if the textual authenticity is doubted or criticised). This is a general principle that has been widely accepted by Muslim scholars. Al-Amidi writes: "If a Quranic verse conflicts with rational argument, the rational argument is preferred and has supremacy." ${ }_{11}$ The "rational argument" Al-Amidi mentions refers to arguments that have reached the level of certainty. His approach is as follows:

If a Quranic verse conflicts with a rational argument there will be three different ways to solve the problem. First: to leave both of them. Second: to implement both of them. Third: to implement one of them and leave another one. The first and the second ways are not possible, so we have to choose the third solution. Then the question is that: which one? By preference of the rational argument we do not put aside the Quranic verse, because we can make its content assigned to some cases so that it does not conflict with the rational argument, while by preference of the verse we will reject the rational argument generally. That is why we prefer the rational argument. ${ }^{52}$

Muslim scholars, in general, have always shown a preference for rational explanations when interpreting controversial Qur'anic verses. For example, Muslim scholars have always applied the concept of specification (takhsis) when explaining general verses of the Qur' an based on a rational argument. ${ }^{53}$ Abu Hamid al-Isfaraini, an eleventh-century Shafi' $i$ master, proclaimed that "there is no disagreement between scholars in the permissibility of takhsis in a Quranic verse based on a rational argument" ${ }^{54}$ If so, one might ask why Muslim scholars have not accepted the abrogation (al-naskh) of Qur'anic verses by rational argument? The general answer is that human reason is not capable of determining when a divine command expires. In theory, Muslim scholars do not 
object to the principle of abrogation of a Qur'anic verse by rational argument, ${ }^{55}$ but since human reason could not determine when a religious injunction expires, abrogation should not be applied. ${ }^{56}$ Al-Jassas sums up the matter as follows:

In fact, this is not the abrogation, but human reason discovers the obstacles prevent[ing] the continuation of the religious ordinance. For example, some of these rules do not persist in the event of a person's inability. In other words, we can say that the human reason discovers the conditions of the religious rule, so, the intellect finds that the command has been conditional or temporary from the beginning. ${ }^{57}$

Most Muslim scholars, regardless of their schools (madhahib), have accepted that, in the event of a conflict between a scriptural (al-naqli) argument and a rational argument, the rational argument takes precedence. Morteza Ansari, a well-known Shiah jurist writes:

The natural and inner intellect, which is not mixed with illusions, is always preferred on the scriptural argument, why not when belief in the existence of God is based on lower level intellect's perception, that is far below the standard of natural intellect. Most researchers believe that a scriptural argument al-naqli cannot stand against certain rational arguments, and if the appearance of such a conflict is found, it should be justified or put aside. ${ }^{58}$

The moderate model differs from the traditional model by calling for a reform in its methods, despite also relying on them. While the traditional method can sometimes extract from the Islamic sources an interpretation consistent with modernity, it is not without some flaws. Thus, many religious statements produced through the traditional method are incompatible with modernity and its achievements. ${ }^{59}$ The shortcomings of the traditional method should not be a reason for abandoning it altogether, but an opportunity to reform and address those shortcomings. This article lists four shortcomings of the traditional method in regard to its compatibility with modernism:

1. The rigidity and inflexibility of established theological foundations. Different Islamic schools have varying theological foundations, and these foundations heavily influence jurists as they extract propositions and legislation from the Qur'an and sunnah. ${ }^{60}$ The attempt to reconcile the texts with their respective theological schools is one of the factors shaping the interpretation of the sacred sources. For example, one of the new theological foundations in religious philosophy is the issue of the individual versus social approach to jurisprudence. ${ }^{61}$ With the individual approach, 'taking 
possession' (al-hiyazah) is considered an absolute and unlimited justification for 'possession.' 62 Therefore, if a person takes empty land which has no visible signs of ownership (e.g. a fence), he then owns it. However, with modern technology, one can now plough and fence an area as large as a town and thereby legitimately own the land according to the individual approach. Adopting a social and managerial jurisprudential approach, however, does not allow unlimited ownership by al-hiyazah.

Another example is determining the scope of shariah in the sphere of governance. There are those who consider the matter of governance and administration to be within the scope of shariah, while others reject this position. ${ }^{63}$

2. The strong influence of jurisprudential schools (madhahib). The followers of each jurisprudential school often validate their respective schools and refuse to refer to outside sources. Such a stance contrasts with the recommended approach of evaluating all narratives and positions based on their authenticity, regardless of their school.

3. Inadequate knowledge regarding the subject matter. The need for scholars to master and understand the subject matter they seek to give an opinion on is crucial. In some cases, Muslim scholars do not fully understand the subject matter, and therefore provide unsatisfactory religious inferences or positions. This problem is even more pronounced when answering modern questions.

4. The perpetuation of false assumptions during the process of religious inference. Many false assumptions result from too much reliance on the human sciences, which are tentative in nature (such as natural sciences, economics, ethics, politics, law, and so on).$^{64}$ This is despite the disciplines themselves undergoing regular adjustments and shifting presuppositions across time. For instance, the cosmological view of traditional Muslim scholars previously centred around Ptolemy ${ }^{65}$ while today it is based on post-Newtonian cosmology. In another instance, the concept of gender equality was previously non-existent and unacceptable, with some scholars even considering women to not be full human beings. Among those who held such a position was Sadr al-Din Muhammad al-Shirazi (1571-1640), a great Shiah Muslim philosopher of the last century, who wrote in his book Hikmah Al-Mutālīyah F̄̄ Al-Asfār Al-'Aqlīyyah Al-Arba'ah:

And among the blessings of God for human is the creation of the different animals which serve him... some of them are created 
for eating... and some for riding... and some for transportation... and some for comfort... and some for marriage (women). ${ }^{66}$

Fast forward to the modern era, the general idea of gender equality has been universally accepted making this view unacceptable. ${ }^{67}$

In the field of law, although the role of religion or faith once occupied a central role in determining rights and responsibility, ${ }^{68}$ today the principle of universal human rights forms the basis of law.

Reforming the traditional method requires rectifying such false assumptions. Mohammad Iqbal Lahouri in his book The Reconstruction of Religious Thought in Islam termed such an endeavour "structural ijtihad". ${ }^{69}$

In brief, by eliminating the four shortcomings of the traditional method, we should be able to avoid the unhealthy influence of particular theological schools, widen the available source material by accepting authentic narrations from all legitimate school of jurisprudence (madhahib), improve competency in addressing new and modern issues, and minimise false assumptions when conducting religious inference.

\section{Conclusion}

The current article attempts to propose a model that will reconcile Islamic teachings with the achievements of modernity. In doing so, the article divides the achievements of modernity into two groups. The first group consists of definitive intellectual conclusions and scientific findings that are accepted by the wise and learned of the world. On the other hand, the second group consists of achievements that are rooted in Western culture or base human desires. The need for a positive and consistent approach should only be limited to the first group, not the second. This method of separating modernity's achievements into two groups is derived from the science of logic as developed by Muslim scholars. If a proposition or statement fulfils the requirements of either alyaqiniyyat, al-mashhurat, or al-musallamat, then it will belong to the first group and therefore be accepted as a legitimate achievement of modernity. Otherwise, it will belong to the second group and be dismissed.

In regard to the proposed model, 'Moderate Islamic Modernism', there are two primary contributions: defining the borders between moderate and extreme Islamic modernism, and, distinguishing the moderate from the traditionalist approach. This article has also pointed out several deficiencies and shortcomings in traditional methods. Reforming the traditional methods will require addressing and solving these problems before interpretations consistent with modernity are provided. This article recommends the following: 
- There is a need for a positive approach to modernity, but its elements must be separated into two groups beforehand. The first comprises definitive intellectual or scientific achievements, while the second includes modern achievements rooted in Western culture and/or base human desires. This article also recommends further fine tuning this method and identifying more case examples.

- Extensive research must be carried out into the impact of the proposed model on the ideas and propositions of modernist Muslims.

- There is a need to identify more case examples regarding the shortcomings of the traditional method.

\section{Notes}

* Javad Fakhkhar Toosi, Department of Islamic Education, Academy of Islamic Studies, University of Malaya, Kuala Lumpur, Malaysia. Email: j.fakhar.t@ gmail.com.

1. Peter Van Der Veer, 'The Global History of "Modernity",' Journal of the Economic and Social History of the Orient 41, no. 3 (1998): 285-94.

2. Tina Di Carlo, 'Postmodern Modernism,' Log no. 24 (2012): 81-5.

3. Van Der Veer, 'The Global History of "Modernity," 81-5.

4. Dhavendra Kumar, 'Engaging with Modernity: Need for a Critical Negotiation,' Sociological Bulletin 57, no. 2 (2008): 240-54.

5. Junqing Yi and Lingmei Fan, 'Dimensions of Modernity and their Contemporary Fate,' Frontiers of Philosophy in China 1, no. 1 (2006): 6-21.

6. Irving Sandler, 'Modernism, Revisionism, Pluralism, and Post-Modernism,' Art Journal 40, no. 1/2 (1980): 345-7.

7. Lapidus Ira Marvin, 'Islamic Revival and Modernity: The Contemporary Movements and the Historical Paradigms,' Journal of the Economic and Social History of the Orient 40, no. 4 (1997): 444-60.

8. Youssef M Choueiri, Islamic Fundamentalism (London: Pinter Publishers, 1990), 54.

9. William Montgomery Watt, Islamic Fundamentalism and Modernity: RLE Politics of Islam (Abingdon: Routledge, 2013), 65.

10. Dietrich Jung, 'Modernity, Islamic Traditions, and the Good Life: An Outline of the Modern Muslim Subjectivities Project,' Review of Middle East Studies 50, no. 1 (2016): 27.

11. Ibid., 18-27.

12. Watt, Islamic Fundamentalism, 47.

13. Mohammed A. Bamyeh, 'Dialectics of Islam and Global Modernity,' Social Analysis: The International Journal of Social and Cultural Practice 46, no. 2 (2002): 81-101.

14. Mustapha Kamal Pasha, 'Islam and the Postsecular,' Review of International 
Studies 38, no. 5 (2012): 1041-56.

15. Jung, 'Modernity, Islamic Traditions, and the Good Life,'18-27.

16. Amina Jamal, 'Gendered Islam and Modernity in the Nation-Space: Women's Modernism in the Jamaat-E-Islami of Pakistan,' Feminist Review no. 91 (2009): 9-28.

17. Marc-Antoine Perouse de Montclos, 'Conversion to Islam and Modernity in Nigeria: A View from the Underworld,' Africa Today 54, no. 4 (2008): 71-87.

18. Dale F. Eickelman, 'Islam and the Languages of Modernity,' Daedalus 129, no. 1 (2000): 119-35.

19. Bassam Tibi, 'Islamic Dream of Semi-Modernity,' India International Centre Quarterly 22, no. 1 (1995): 79-87.

20. Soroush Dabbagh, Religion in the Mirror: An Overview of Abdul Karim Soroush's Religious Views (Tehran: Srat Publisher, 2006).

21. Mohammad Mojtahed Shabestari, Hermeneutics, the Book and Tradition (Tehran: Tarhe New, 2006).

22. Khosropanah Abdolhossein, 'Islam and Modernity,' Kalam Islami 22, no. 85 (2013): 125-40.

23. Seyyed Vali Reza Nasr, Mawdudi and the Making of Islamic Revivalism (Oxford: Oxford University Press on Demand, 1996).

24. David Arnott and Graham Pervan, 'The Methodological and Theoretical Foundations of Decision Support Systems Research,' in Information Systems Foundations: Theory, Representation and Reality, ed. Dennis N Hart and Shirley D Gregor (Canberra: ANU Press, 2007), 247-62.

25. Ibid.

26. George Groenewold and Laurence Lessard-Phillips, 'Research Methodology,' in The European Second Generation Compared, Does the Integration Context Matter? ed. Maurice Crul, Frans Lelie and Jens Schneider (Amsterdam: Amsterdam University Press, 2012), 39-56.

27. Husiyn ibn Abdillah Avicenna, Al-Shifa': Natural Sciences, vol. 2 (Qom: Mar'ashi Library, 1984), 79.

28. Abd al-Qahir Al-Jurjani, Al- Ta 'rifat (Tehran: Nasir Khusru Publisher, 1992), 35 .

29. Shahib al-Din Yahya ibn Habash Suhrawardi, Majmuah Musannafati Sheikh Ishraq:Hikmah Al-Ishraq (Tehran: Institute for Cultural Studies and Research, 1996), 234.

30. Ibid., 41.

31. Husiyn ibn Abdillah Avicenna, Al-Shifa': Logic, vol. 2 (Qom. Iran: Mar'ashi Library, 1984), 22

32. Ibid.

33. Ibid.

34. Jung, 'Modernity, Islamic Traditions, and the Good Life,' 18-27.

35. Mehrdad Kia, 'Nationalism, Modernism and Islam in the Writings of Talibov-I Tabrizi,' Middle Eastern Studies 30, no. 2 (1994): 201-23.

36. Abdulkader Tayob, 'Dialectical Theology in the Search for Modern Islam,' in Islamic Studies in the Twenty-First Century: Transformations and Continuities, ed. Léon Buskens and Annemarie van Sandwijk (Amsterdam: Amsterdam University Press, 2016), 161-82. 
37. Mohammed Hashas, 'Abdolkarim Soroush: The Neo-Mu'tazilite that Buries Classical Islamic Political Theology in Defence of Religious Democracy and Pluralism,' Studia Islamica 109, no. 1 (2014): 147-73.

38. I mean by these two groups the achievements based on definite scientific ideas (or human reason) and achievements based on Western life style, type of education, environmental influences, human instincts and so on.

39. Hashas, 'Abdolkarim Soroush' 147-73.

40. Yasuyuki Matsunaga, 'Human Rights and New Jurisprudence in Mohsen Kadivar's Advocacy of "New-Thinker" Islam,' Die Welt des Islams 51, no. 3/4 (2011): 358-81.

41. Yahya Ibn Sharaf Al-Nawawi, Rawdhah Al-Talibin Wa 'Umdah Al-Muftin, vol. 8 (Beirut: Dar al Kutub al-'Ilmiyah, 1991), 83.

42. Ibid.

43. Mahmoud Sadri, 'Sacral Defense of Secularism: The Political Theologies of Soroush, Shabestari, and Kadivar,' International Journal of Politics, Culture, and Society 15, no. 2 (2001): 257-70.

44. Ibid.

45. Al-Nawawi, Rawdhah Al-Talibin, vol. 8, 83.

46. Abdullah ibn Umar Al-Baydawi, Anwar Al-Tanzil Wa-Asrar Al-Ta'wil, vol. 1 (Beirut: Dar Ihya al-Turath al-Arabi, 1997), 127.

47. Ali ibn Abi Bakr Al-Haythami, Majma' Al-Zawa'id Wa Manba' Al-Fawa'id, vol. 1 (Beirut: Dar al Kutub al-'Ilmiyah, 1988), 98.

48. Abu Zahra, 'Ilm Usul Al-Fiqh, 28.

49. Charles D. Fletcher, 'The Methodology of Abdolkarim Soroush: A Preliminary Study,' Islamic Studies 44, no. 4 (2005): 527-52.

50. Ibid.

51. Sayf al-Din al-Amidi, Al-Ihkam Fi Usul Al-Ahkam, vol.2 (Damascus: al-Maktab al-Islami, 1982), 152.

52. Ibid., 316.

53. Ahmad ibn Ali al-Razi al-Jassas, Al-Fusul Fi Al-Usul (Kuwait: Kuwait Ministry of Awqaf, 1994), 146-7.

54. Ibid.

55. Ibid., 149.

56. Ibid., 151.

57. Ibid.

58. Morteza al-Ansari, Fara'id Al-Usul, vol. 1 (Tehran: Islamic Publishing Corporation 1995), 18.

59. Basit B. Koshul, 'Fazlur Rahman's "Islam and Modernity" Revisited,' Islamic Studies 33, no. 4 (1994): 403-17.

60. Ibid.

61. Tayob, 'Dialectical Theology in the Search for Modern Islam,' 161-82.

62. Yahya Ibn Sharaf Al-Nawawi, Al-Majmu' Sharh Al-Muhadhdhab, vol. 15 (Beirut. Lebanon: Dar al-Fikr, 1987 ), 211.

63. Ismail Sirageldin and Muhammad Anwar, 'Islam, Society, and Economic Policy [with Comments],' The Pakistan Development Review 34, no. 4 (1995): 457-80; Fait A. Muedini, 'Teaching "Islam and Human Rights" in the Classroom,' $P S$ : Political Science and Politics 45, no. 1 (2012): 101-5. 
64. Hashas, 'Abdolkarim Soroush,' 147-73.

65. See, 'Ali ibn Mohammed Al-Jurjani, Sharh Al- Mawaqif, vol. 7 (Beirut: Dar alKutub al-Ilmiyyah, 1998), 80.

66. Sadr al-Din Muhammad al-Shirazi, Hikmah Al-Mutaliyah Fi Al-Asfar Al'Aqliyah Al-Arba'ah, vol. 7 (Beirut: Dar Ihya al-Turath al-'Arabi, 1981), 137.

67. Nils-Petter Lagerlöf, 'Gender Equality and Long-Run Growth,' Journal of Economic Growth 8, no. 4 (2003): 403-26.

68. Zehra F. Kabasakal Arat, 'Human Rights Ideology and Dimensions of Power: A Radical Approach to the State, Property, and Discrimination,' Human Rights Quarterly 30, no. 4 (2008): 906-32.

69. Muhammad Iqbal Lahouri, Regenerating the Religious Thought in Islam, trans. Ahmad Aram (Tehran: Regional Cultural Institute, 1967): 57. 